HEME BIOLOGY

The Secret Life of Heme in

Regulating Diverse Biological Processes 
This page intentionally left blank 


\section{HEME BIOLOGY}

The Secret Life of Heme in Regulating Diverse Biological Processes

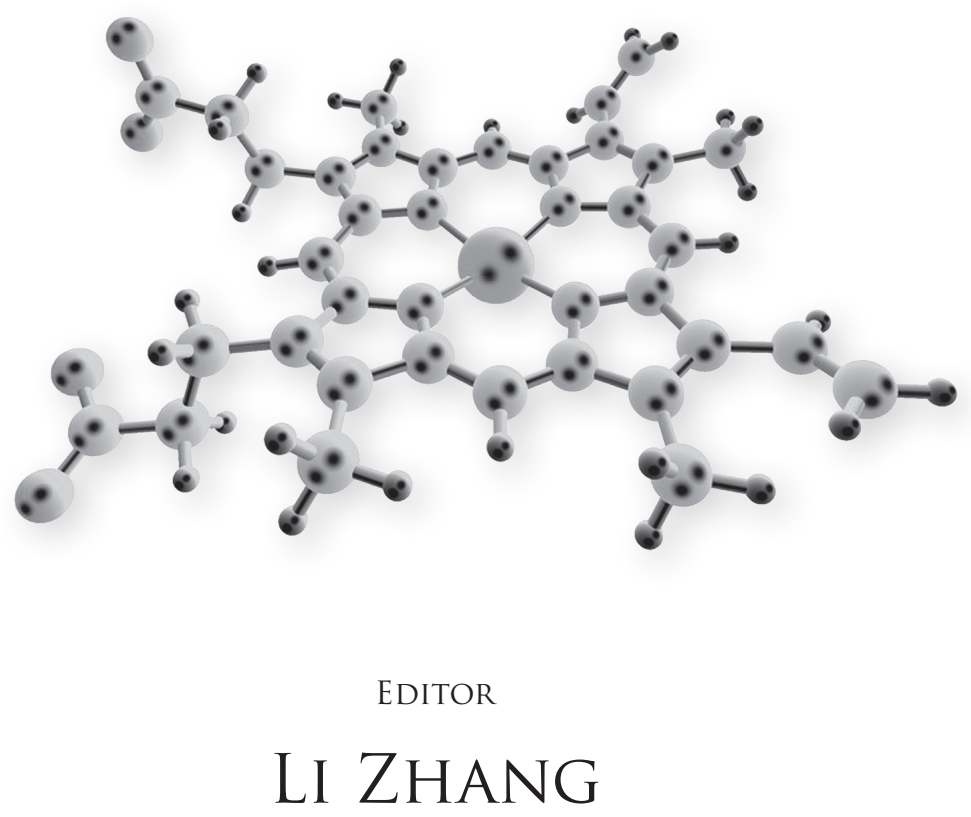

The University of Texas at Dallas, USA 
Published by

World Scientific Publishing Co. Pte. Ltd.

5 Toh Tuck Link, Singapore 596224

USA office: 27 Warren Street, Suite 401-402, Hackensack, NJ 07601

UK office: 57 Shelton Street, Covent Garden, London WC2H 9HE

\section{British Library Cataloguing-in-Publication Data}

A catalogue record for this book is available from the British Library.

\section{HEME BIOLOGY \\ The Secret Life of Heme in Regulating Diverse Biological Processes}

Copyright (C) 2011 by World Scientific Publishing Co. Pte. Ltd.

All rights reserved. This book, or parts thereof, may not be reproduced in any form or by any means, electronic or mechanical, including photocopying, recording or any information storage and retrieval system now known or to be invented, without written permission from the Publisher.

For photocopying of material in this volume, please pay a copying fee through the Copyright Clearance Center, Inc., 222 Rosewood Drive, Danvers, MA 01923, USA. In this case permission to photocopy is not required from the publisher.

ISBN-13 978-981-4287-92-0

ISBN-10 981-4287-92-X

Typeset by Stallion Press

Email: enquiries@stallionpress.com

Printed in Singapore. 
To my mother, Shi-Fong Wu, and father, Chang-Gui Zhang 
This page intentionally left blank 


\section{PREFACE}

Heme biology aims to provide a cohesive understanding of the fundamental regulatory and signaling roles of heme in life and disease processes, as well as the underlying chemical and molecular basis. Heme is arguably the most ubiquitous and unique molecule in the human body. It gives our blood the distinctive color and plays key roles in the proper functioning of all cells. This book provides an in-depth analysis of the roles of heme in three types of human tissues, reticulocytes, brain and liver, on which heme exerts crucial effects.

Heme biology links human function and diseases to the molecular and cellular events occurring in cells, as well as the structural and chemical features of heme. It describes how heme is made, how its level is regulated in various tissues, and what kinds of diseases ensue when the heme level becomes dysregulated. It describes in detail key protein macromolecules with which heme can interact with and thereby control their activities. It also sheds light on how altered interactions between heme and proteins can lead to dysregulated molecular and cellular processes, which in turn cause human diseases. This book includes information about how the chemical properties of heme and heme analogs can be applied to cancer therapy. Overall, this book can be informative and insightful to both the general curious readers and advanced researchers interested in heme biology. 
This page intentionally left blank 


\section{CONTENTS}

Preface vii

List of Contributors $\quad$ xi

Chapter 1 Introduction 1

Li Zhang

Chapter 2 Heme Biosynthesis and Degradation: What Happens $\quad 7$ when it goes Haywire?

Li Zhang and Rebekah Sessoms

Chapter 3 Heme: An Ingenious Regulator

of Gene Transcription

Li Zhang

Chapter 4 Heme-Regulated eIF2 $\alpha$ Kinase in Translation and Erythropoiesis

Jane-Jane Chen and Rajasekhar NVS Suragani

Chapter 5 Role of Heme in Brain Functions: Dr. Jekyll or Mr. Hyde?

Tatyana Chernova and Andrew G. Smith

Chapter 6 Heme and microRNA Biogenesis

Feng Guo 
Chapter 7 The Vast Potential of Heme in Regulating Biological Processes: A Global Perspective Li Zhang, Aaron Arvey, Donovan Pham Huynh and Christina Leslie

Chapter 8 The Chemical and Structural Bases of Heme

Recognition: Binding Interactions of Heme with

Proteins and Peptides

Y. Li and Li Zhang

Chapter 9 Clinical Applications of Heme Biosynthetic Pathway: Photodynamic Therapy with Protoporphyrin IX Huiying Ding, Baran D. Sumer and Jinming Gao

Index 


\section{LIST OF CONTRIBUTORS}

\section{Jane-Jane Chen and Rajasekhar NVS Suragani}

Harvard-MIT Division of Health Sciences and Technology, Massachusetts Institute of Technology, 77 Massachusetts Avenue, Cambridge, MA 02139

\section{Huiying Ding, Baran D. Sumer, and Jinming Gao}

Department of Pharmacology, Department of Otolaryngology, Simmons Comprehensive Cancer Center, University of Texas Southwestern Medical Center, Dallas, Texas 75390

\section{Feng Guo}

Department of Biological Chemistry, UCLA School of Medicine, Box 951737, 337 BSRB, Los Angeles, CA 90095-1737

\section{Li Zhang, Yi Li, Rebekah Sessoms, and Donovan Pham Huynh}

Department of Molecular and Cell Biology, The University of Texas at Dallas, Mail Stop FO31, 800 W. Campbell Road, Richardson, TX 75080

\section{Aaron Arvey and Christina Leslie}

Computational Biology Program, Memorial Sloan-Kettering Cancer Center, 1275 York Ave, Mail Box \#460, New York, NY 10065

Tatyana Chernova and Andrew G. Smith MRC Toxicology Unit, University of Leicester, United Kingdom 